\title{
Entrevista
}

\section{Carles Duarte}

Carles Duarte i Montserrat (Barcelona, 1959) és autor d'una extensa obra poètica (Triptic hebreu, El somni, El silenci, El centre del temps...), que ha estat àmpliament traduïda, i de diversos llibres de lingüística. Va rebre el Premi de la Crítica Serra d'Or de Poesia de 2004.

- Connexions entre la literatura catalana, gallega i basca.

Les relacions entre la literatura catalana, gallega i basca són antigues $\mathrm{i}$ profundes, sobretot en el cas de la gallega i la catalana. Des de l'època medieval pels lligams comuns amb la literatura trobadoresca, per exemple, i és evident que durant el s. XX va haver-hi molts moviments sobretot quan els processos de recuperació cultural de Catalunya, el País Basc i Galícia van anar adquirint consistència; va ser que els lligams van esdevenir molt explícits. De fet Galeusca ja n'era una primera plasmació i de fet avui les associacions d'escriptors catalana, gallega i basca continuen recuperant aquell nom de Galeusca promovent trobades d'escriptors de les tres literatures. Per tant hi ha una relació no tan sols històrica sinó ben real i ben immediata. No vol dir que no puguin ser més, però cal reconèixer la importància d'aquestes trobades que amb el nom de Galeusca representen ocasions de col-laboració, d'entesa, de coneixement entre escriptors de les tres literatures i això continua ben viu.

-A quines literatures "grans» deuen més aquestes literatures «petites», si és que «deuen» alguna cosa?

Des del punt de vista de la tradició, la literatura catalana amb figures com Llull, com March, o com el Tirant lo Blanc o com Verdaguer, és una literatura d'una gran consistència que només és comparable a les deu millors literatures del món. No podem situar la literatura catalana en un nivell inferior a la literatura japonesa, per exemple, o a la literatura argentina o xilena, encara que no hi hagi cap premi nobel català. Per la dimensió històrica i per la qualitat d'algunes de les seves figures, la literatura catalana és una literatura molt important. D'una manera diferent, és clar, en la literatura gallega sempre hi ha aquest component complex de la relació entre el món gallec, el món brasiler i el món portugés des del punt de vista de la literatura perquè la literatura brasilera, portuguesa $i$ 
gallega ténen lligams molt íntims i per tant si, d'alguna manera, entenem que la literatura gallega no tan sols és la gran literatura medieval sinó que, a més a més, avui, a part dels escriptors més consagrats en gallec, té lligams tan directes i tan profunds amb els grans escriptors portuguesos i brasilers, doncs, l'hem de tractar amb molt de respecte. I pel que fa a la literatura basca, és una literatura que té unes arrels més diferents perquè el món cultural en èuscar potser és ara que viu un dels períodes més exuberants des del punt de vista de la seva creativitat i no trobaríem a l'edat mitjana autors equiparables als grans noms gallecs o catalans. Pel que fa a les relacions d'aquestes literatures amb d'altres literatures majors, és evident que la literatura gallega és la mare de la literatura portuguesa i la mare de la literatura brasilera, aixó és un fet inqüiestionable ja que històricament és així, i per tant té una relació directíssima de paternitat d'una de les literatures més importants del món. I pel que fa a la literatura catalana és evident que des del mateix Quixot que elogia l'obra de Tirant lo Blanc, fins a la difusió enorme que Ausiàs March i tants d'altres autors catalans medievals van tenir, va ser i és al capdavall una literatura molt influent des del punt de vista del que ha estat la literatura occidental: $n$ 'hi ha prou de llegir el que ens diu Harold Bloom als seus llibres. La literatura catalana és una literatura que viu un període que, sobretot des del moment de la Reinaxença i encara més amb el Modernisme i el Noucentisme, fa una aposta forta per sortir d'un escenari d'aillament $i$, per tant, la literatura catalana s'ha enriquit amb moltes traduccions, per exemple les que es publicaven a L'Avenç o les que s'han publicat evidentment dels clàssics de la col-lecció Bernat Metge, però sobretot em refereixo al criteri d'incorporació, de relació i de lligam dels escriptors catalans amb els seus contemporanis; $i$, en això, sobretot el Modernisme i especialment també el Noucentisme van ser molt importants, tot i que ja a la Reinaxença les relacions amb Frederic Mistral són clares. Per tant, la literatura catalana no és una literatura aillada, només ho ha estat en períodes determinats de la seva història, però hi ha una voluntat d'obertura, d'incorporació, d'aprenentatge i d'incidència. Per tant des d'aquesta prespectiva és una literatura molt desinhibida i molt reconeguda amb normalitat en el context internacional. La prova seria la seva presència a la Fira de Guadalajara o a la Fira de Frankfurt en que només hi són literatures d'abast i d'interès per la gent de tot el món.

-Moltes vegades ens trobem que s'accedeix a la literatura catalana, gallega o basca des de la literatura castellana, potser per ignorància o per desconeixement, o perquè es tracta d' estudiants que arriben a Espanya $i$ s'hi troben un calidoscopi de literatures que potser no s'esperaven. Sota el teu punt de vista, ¿quins noms es podrien recomanar per iniciar aquest camí? Podries diferenciar entre poesia i narrativa?

Sens dubte la llengua castellana és una de les llengües més parlades i llegides del món i per tant, en el context espanyol, és del tot natural que hi hagi persones que s'introdueixin a la literatura catalana a partir de les traduccions en castellà $\mathrm{i}$ això no ens ha de sorprendre: és natural, positiu i està molt bé. Com també és positiu i està molt bé que es tradueixin els autors catalans, gallecs i bascos a altres llengües, com ja es fa, al francès, a l'italià, a l'anglès, a l'alemany, etc. A mi em sembla que és rellevant tot l'esforç que es pugui dur a terme perquè aquestes traduccions es produeixin i en alguns casos amb un èxit molt evident, 
com pot ser en el cas del català de Mercè Rodoreda o Jesús Moncada. La traducció no deixa de ser en certa manera un examen de qualitat i es tradueix sobretot allò que és capaç d'anar més fàcilment al cor o commoure i trasbalsar també l'ànim i l'esperit i inquietar literàriament els lectors d'altres cultures. La traducció en aquest sentit fa que determinades obres, algunes formidables, tinguin certes dificultats perquè de vegades responen a plantejaments i a models literaris que són molt difícils de traslladar a altres literatures. Hi ha un punt d'universalitat que no sempre és fàcil d'aconseguir en una obra literària. I és cert que hi ha obres literàries catalanes que han demostrat que són, des d'una gran especificitat, perquè en alguns casos com Moncada és així, com ho pot ser també García Márquez, un home que té un ressò internacional amb una obra molt personal i molt arrelada a un paisatge, però plantejada, com en el cas d'en Moncada o Mercè Rodoreda, amb una ambició i amb una saviesa literària $i$ humana que les fa capaces de ser percebudes com a obres mestres també per lectors de diverses literatures. Jo crec que cal fer un esforç perquè la literatura catalana surti encara més del seu espai d'autoreconeixement i que se sotmeti a aquest examen que representa la traducció, que es vegi si aquestes obres traduides són també obres estimades i apreciades per lectors d'altres països. Pel que fa a la prosa o a la poesia, és evident que la narrativa, ja en el mercat intern però òbviament també en el mercat internacional, té una difusió més gran que la poesia llevat de casos excepcionals. Hi ha noms com els que he esmentat $\mathrm{i}$ també noms com Carme Riera o Baltasar Porcel que, pel que fa a la narrativa, són autors contemporanis d'una gran solidesa i són autors capaços d'interessar. En el cas de la poesia, nosaltres hem tingut algunes mancances i algunes dificultats perquè grans autors catalans han tingut dificultats per ser traduîts i per ser presents en altres literatures, potses precisament el component més accentuat de la música o de l'impacte literari de determinades metàfores queda en certa manera perdut o disminuiit des del punt de vista de l'eficàcia literària en les traduccions. Això pot explicar que alguns poetes catalans, molt llegits i molt apreciats al nostre país, hagin estat poc traduitts $i$, quan han estat traduits, també han tingut dificultats per tenir un reconeixement molt ampli, com per exemple Miquel Martí i Pol que ha estat i és un autor català molt important però en canvi amb una limitada projecció internacional, tot i la importància indiscutible de la seva obra. Ara, jo penso que hi ha un interès creixent per la poesia catalana en altres llengües i la meva experiència personal, que és la d'algú que ha estat traduït amb frequiència al francès, a l'italià, a l'hebreu i altres llengües, és una experiència satisfactòria perquè t'adones que, gràcies a la qualitat de les traduccions, són obres que han tingut una bona recepció a les respectives literatures. Amb independència que la poesia catalana cada vegada és una poesia més valorada i més respectada internacionalment (jo assisteixo, per exemple, a reunions de l'Acadèmia Mundial de la Poesia o de l'Acadèmia Europea de la Poesia, i això no deixa de ser un signe de normalitat i de reconeixement), hi ha molt de camí per còrrer. Jo crec que això també succeeix en el cas de l'èuscar o del gallec.

En aquests moments de la teva obra, que has escrit molt, que has guanyat molts premis, que ets un dels poetes més traduits de la literatura catalana, si fessis un balanaç del que perseguies quan començaves, ¿creus que la recerca ha 
estat fructifera? Has trobat el que buscaves? El que buscaves ha anat mutant al llarg del temps? Quina valoració en fas de la teva obra?

Bé, jo vaig començar a escriure fa més de trenta anys i se'm fa difícil fer-ne una valoració breument. Vaig començar des de la lectura d'altres poetes, des de l'entusiasme i des de la passió i amb una voluntat d'aconseguir una obra personal. Al cap dels anys, la meva obra ha anat obrint-se d'entrada cap a altres territoris molt més enllà dels de la meva experiència personal $i$, a més de traduir altres autors, com l'Helene Dorion, $m$ 'he endinsat i continuo fent-ho amb insistència perquè ho considero un enriquiment en el món dels referents literaris culturals i espirituals d'Egipte, d'Israel, de Grècia, de Roma... Per tant, la meva obra s'ha anat eixamplant i ha anat més enllà de la prespectiva merament personal. També ho ha fet amb la col-laboració creixent $\mathrm{i}$ insistent amb pintors, fotògrafs, escultors... Són molts els llibres que he escrit i els treballs que estic fent ara en col-laboració amb tota mena de creadors d'altres llenguatges artístics. Per tant, des d'aquesta perspectiva sí que la meva obra ha evolucionat molt i s'ha anat articulant d'una forma molt més complexa. Jo crec que d'una obra literària mai en pots estar satisfet. Senzillament, el que hi ha és la consciència dels límits i l'anhel de dur l'escriptura cap a moments de més plenitud.

\section{-Quan escrius poesia, et busques més a tu mateix o al lector?}

Bé, en la poesia que jo em plantejo d'escriure, hi ha un compromís amb la literatura i amb el lector. No crec en el narcisisme literari. No m'entusiasma. La meva poesia té una dimensió que va més enllà de l'experiència, que s'endinsa en l'ètica, en el paisatge, en el diàleg amb els altres i amb el reconeixement d'unes arrels culturals, amb l'esforç per enlairar l'expressió poètica gràcies a la construcció compartida amb d'altres artistes. No és un exercici d'entotsolament la meva obra literària. En tot cas, el que em sembla indispensable és, com Martí Pol i com tants altres autors, que «en cada mot $m$ 'hi jugo l'existència». El poeta que no s'hi juga tot a cada poema juga amb un nivell de limitacions molt elevat perquè al capdavall el lector ho intueix i li ho retreu. A mi em sembla que la poesia, com l'art, ha de ser agosarada, valenta, i exigeix compromís.

Les generacions actuals que vénen al darrera, després de tants noms com el teu, com el de Màrius Sampere, com el de Martí Pol, com el de Palau i Fabre, com el de Margarit, com el de tants..., com veus el panorama actual?

Jo crec que són millors que nosaltres. Estic molt content perquè dins la literatura catalana no tinc la sensació de fatiga, de reiteració, no tinc la percepció d'ensopiment, d'encongiment, no, no. A mi em sembla que la gent jove escriu millor que molts de nosaltres quan teníem la seva edat. Això fa que tingui molta il·lusió en les noves generacions literàries. El que sí que reclamo és que surtin més, que viatgin més, que coneguin més escriptors d'altres literatures. Això sí que crec que els ho hem de demanar als escriptors, tant als catalans, com als gallecs, com als bascos, com als castellans. Que tinguin una presència internacional més gran, que depèn per descomptat de les traduccions que es facin, però també del seu esforç personal de voler construir amistats amb autors amb criteris estètics propers. En alguns casos ja és així i el que cal és que això sigui cada vegada més freqüent. Ara, des del punt de vista de l'ambició, del talent, de la qualitat, em sembla que estem davant de generacions interessantíssimes. 
-Darrerament, tot i que ja ho havies fet en anteriors moments de la teva trajectòria literària, has refermat el pas cap a la narrativa amb Ulls encendrats, d'ed. 3 i 4 , però evidentment el teu corpus sempre s' ha mantingut en la vessant poètica. Què és el que t' ofereix la narrativa que potser no t'ofereix la poesia i que t'ogligui a fer el pas d' utilitzar un llenguatge tan diferent?

Bé, jo no ho plantejaria com una obligació, el que passa és que hi ha projectes literaris, hi ha idees, hi ha missatges, hi ha emocions, que s'expressen millor amb poesia, i n'hi ha que necessiten la prosa. Jo no m' he plantejat mai, ni crec que de moment ho faci, l'escriptura d'una novel-la, o d'una narració més completa, entre d'altres coses perquè jo em moc molt més còmodament $\mathrm{i}$ em sento molt més atret per la concisió, per un text on el fil del que es vol dir es va eixamplant i es va engruixint amb històries que s'encreuen. Que ho trobo per descomptat interessantíssim com a lector, però no des de la perspectiva de qui es proposa escriure-ho. El que m'interessa sobretot és la intensitat, l'emoció, la reflexió, la interrogació, la integració, i en això la poesia o la narració breu constitueixen Ilenguatges amb què em puc trobar molt a gust. És cert que hi ha determinades impressions d'escenaris humans i d'escenaris d'expressió de la naturalesa que es reflecteixen molt més colpidorament amb una metàfora, amb una imatge, amb un poema, en canvi hi ha d'altres que són potser més reflexius, tot i que també n'he escrit de poemes reflexius que, al capdavall, el que fan és despertar un neguit en el lector que potser en la narració breu encaixa millor. Tot i així, tant en la poesia com en la narració els eixos de la meva literatura són coincidents perquè sempre hi ha el somni, la tendresa, l'oblit, com a columnes que sostenen tot el meu edifici literari, tant si és en prosa com si és poesia.

-M'agradaria fer un esment a la Fira de Frankfurt de l'any que ve, on la literatura catalana hi serà la convidada. Crec que és un orgull, tant pels catalans com per tots els espanyols, el fet que una literatura nostra estigui present en una fira tan important. Hi ha una mica de debat en tot això: qui hi ha de ser $i$ qui no? què és literatura catalana, només l'escrita en català? per exemple Vázquez Montalbán o Eduardo Mendoza, hi han de ser o no?

Crec que aquest tipus de propostes i d'ocasions són fruit de la voluntat de projectar i de reconèixer una determinada literatura però també el territori cultural on aquesta literatura es desenvolupa, es genera i creix. La literatura catalana és l'escrita en català, per mi és bastant clar que és així. L'Eduardo Mendoza, que estimo i respecto moltíssim, és lògic que aparegui als manuals de literatura castellana, i no és un autor que hagi de sortir als manuals de literatura catalana. El que succeeix és que a l'hora de projectar la literatura catalana i la literatura a Catalunya, em sembla que és bo que a Frankfurt, a més de posar l'accent en allò que singularitza Catalunya en relació amb altres territoris on s'escriuen obres literàries rellevants en castellà, és el fet que hi ha una literatura que arrenca de l'edat mitjana i que continua tenint una gran vitalitat que és la literatura catalana. Per tant, l'èmfasi em sembla que s'ha de posar en la literatura catalana, en allò que singularitza Catalunya en el context literari internacional, però seria una manera poc afortunada de presentar la realitat cultural literària de Catalunya si s'hi apliqués un criteri d'exclusió i que només hi fossin presents en aquesta fira autors que escriuen en català. Tot i que hi hagi una atenció preferent per allò que 
més singularitza, seria desitjable que també hi fossin autors que escriuen també a Catalunya que conviuen amb els escriptors que escriuen en català i que, per tant, formen part del mateix teixit literari, encara que no de la mateixa literatura. Crec que és bo que alguns d'aquests autors acompanyin als escriptors en llengua catalana i que formin part de la manera com Catalunya es presenta al món del llibre internacional en aquesta fira de Frankfurt.

-Molts dels teus llibres han estat publicats en format bilingüe. Hi ha una sèrie d' escriptors catalans que viuen el bilingüisme com un fet normal i natural però a l'hora d' escriure han de triar i es converteix en un problema, ja que no només s' està escollint una llengua sinó tota una tradició literària. És una decisió que han de prendre i se'ls presenta com un entrebanc.

Viure és triar i és dubtar. En el cas d'una obra literària també. Hi ha autors que escriuen en les dues llengües, el mateix Eduardo Mendoza ha escrit teatre en català. Hi ha autors catalans que escriuen en castellà - jo mateix - i en anglès i en altres llengües. Ara, em sembla que és important que cadascú prengui opció i és una opció que té a veure amb la relació que té cadascú amb les llengües, $\mathrm{i}$ quina considera que és la que el pot dur més enllà com a escriptor, on pot innovar, on pot crear d'una manera més valenta, més convincent, més capaç de sorprendre i de tensar la literatura per descobrir-hi, per commoure, per sacsejar. És una decisió molt personal i en això pot haver-hi tota mena de lectures i tota mena de factors però l'aspecte clau és l'estrictament literari. Com deia abans, els escriptors s'han de jugar en cada mot l'existència, sobretot en poesia, i has de saber amb quina llengua pots anar més enllà, no des del punt de vista de la projecció literària, que això és un error, em sembla un engany, ja que la literatura, per l'escriptor, com jo l'entenc, és sobretot creació, com un pintor crec que no ha de triar la tècnica en funció de l'èxit que pugui tenir sinó en funció de com el seu art pot arribar a ser més inèdit i més colpidor; passa amb la música, amb la literatura, amb la pintura, i és un aspecte bàsic en una decisió d'aquest tipus.

(Mireia Vidal-Conte). 